\title{
Characterization of the Physicochemical and Biological Properties of Kombolcha Brewery Wastewater Treatment Plant Bio-solid in Relative to Agricultural Uses
}

Ermias Alayu*, Seyoum Leta and Temesgen Aragaw

Centre for Environmental Science, College of Natural Science, Addis Ababa University, Ethiopia

*Corresponding author: Alayu E, Centre for Environmental Science, College of Natural Science, Addis Ababa University, Ethiopia, Tel: +251920257482; E-mail: ermias.alayu@gmail.com

Received: January 24, 2018; Accepted: February 09, 2018; Published: February 15, 2018

Copyright: (c) 2018 Alayu E. This is an open-access article distributed under the terms of the Creative Commons Attribution License, which permits unrestricted use, distribution, and reproduction in any medium, provided the original author and source are credited.

\begin{abstract}
Agro-industrial sectors in Ethiopia are highly expanding and offering environmental problems. Some brewery factories in Ethiopia had installed advanced wastewater treatment technologies. Sludge generated from waste treatment plants are recognized as good alternative options for agricultural reuse. However, the difference in sludge properties due to the wastewater action process variation and the inconstant nature of contaminant inputs to the original wastewater, the fertilizer prospective and contaminant risks should be evaluated. Hence, the goal of this study was to illustrate the physical, chemical and biological properties of Kombolcha brewery wastewater treatment plant bio-solid in relative to agricultural reuse. The physicochemical and biological characteristics of the brewery sludge were 7.85, $2.35 \mathrm{mScm}^{-1}, 54 \%, 92.9 \%, 49.1 \%, 84.6 \%, 3.84 \%, 5.92 \%, 12.78: 1,5.46 \mathrm{CFU} / \mathrm{ml}$ and $3.06 \mathrm{CFU} / \mathrm{ml}$ for $\mathrm{pH}, \mathrm{EC}, \mathrm{WHC}, \mathrm{TS}, \mathrm{OC}, \mathrm{OM}, \mathrm{TKN}, \mathrm{P}_{2} \mathrm{O}_{5}, \mathrm{C} / \mathrm{N}$ ratio and TFC (as fresh and dry weight) respectively. The secondary and other plant nutrient contents of the BS were $0.24 \%, 1.61 \mathrm{mg} / \mathrm{Kg}$ for $\mathrm{K}_{2} \mathrm{O}$ and $\mathrm{K}, 4.74 \%, 3.19 \mathrm{mg} / \mathrm{Kg}$ for $\mathrm{CaO}$ and $\mathrm{Ca}, 0.76 \%, 1.19 \mathrm{mg} / \mathrm{Kg}$ for $\mathrm{MgO}$ and $\mathrm{Mg}, 0.86 \%, 0.37 \mathrm{mg} / \mathrm{Kg}$ for $\mathrm{Na}_{2} \mathrm{O}$ and $\mathrm{Na}, 2.94 \%$ for $\mathrm{Al}_{2} \mathrm{O}_{3}$, $27.98 \%$ for $\mathrm{SiO}_{2}$ and $0.18 \%$ for $\mathrm{TiO}_{2}$ with the detected heavy metals concentration of $0.07,0.05,10211.5$ and 0.77 $\mathrm{mg} / \mathrm{Kg}$ for $\mathrm{Zn}, \mathrm{Pb}, \mathrm{Fe}$ and $\mathrm{Cu}$ respectively. Overall, the result revealed that the sludge has high $\mathrm{OM}$ and $\mathrm{P}_{2} \mathrm{O}_{5}$ content that fulfills the suggested standards for the fertilizer value of sludge, optimum $\mathrm{pH}$ and $\mathrm{EC}$ values, substantial qualities of nitrogen and high WHC and deficient secondary plant nutrients (calcium, magnesium, potassium and sodium), all able to contribute beneficial improvement of soil properties. In line with this, the very lower heavy metals concentration, existed below both the EPA and Canadian class A limits and ideal $\mathrm{C} / \mathrm{N}$ ratio, meets the fertilizer value of sludge and make it to serve as a valuable organic fertilizer. However, the higher pathogen contents are stabilized to the required standard $(<10-3)$ for unrestricted reuse of the sludge for agricultural application.
\end{abstract}

Keywords: Advanced wastewater treatment; Brewery sludge fertilizer potential; Plant nutrients; Waste management

\section{Introduction}

Agro-industrial sectors in Ethiopia are highly expanding sector along with increasing in their production capacity to hold a planned economic position, but they offer substantial challenges to the environment $[1,2]$. Among these, beverage industry discharges large amount of wastes that contains high strength organic pollutants which are hazardous to the environment [3]. Currently in Ethiopia, some brewery industries adopted advanced wastewater treatment technologies composed of screening, equalization, up-flow anaerobic sludge blanket (UASB) process extended with aeration followed by final polishing unit (FPU) to manage their liquid waste in an environmentally sustainable way. The sludge generated from the aerobic unit undergoes dewatered using belt pressing process, collected in sedimentation tank and transported to land disposal. Disposal of sludge has been very costly, often requiring over $50 \%$ of the operators budget for wastewater treatment plant [4], besides causing environmental problems. Among the different sludge disposal methods, landfilling is the common one. Whereas, land application is an alternative option to avoid the high landfill cost, available land space limitation as well as hygienic problems [5].
Therefore, disposal of sludge in a sustainable approach has got a global attention [6], and has a great significance to local communities, authorities and the industry. Brewery industry discharging large volumes of organic materials (spent grain, yeast, kieselguhr and sludge) with each brewing. Such disposal of brewery sludge gets consideration to look available options to manage it in an eco-friendly manner either alone or combined with others for agricultural practices to increase crop yields from a limited area by reducing more chemical fertilizers and pesticides [7-9]. Most research investigation results showed that land application of agro-industrial wastewater treatment plant sludges for agricultural purposes is an ultimate disposal alternative option without any hazardous effect for soil conditioner [10-12]. However, sludges intended for agricultural use may contain toxic metals, persistent organic pollutants and pathogens that cause harmful effects to humans through transmission into the food chain [13].

Generally, the increases in the amount of sludge generation from waste treatment plants bring significant pressure on its disposal method. Therefore, use of these waste materials for land application is increasingly being identified as an important issue to address the problem [14]. The characteristics of brewery sludge make it one of the most interesting material for agricultural reuse particularly to cropland and forested lands instead of straight disposals, due to the possibility of recycling its appreciated plant nutrients (nitrogen and phosphorus) to plant growth $[15,16]$. Kombolcha brewery wastewater treatment plant 
Citation: Alayu E, Leta S, Aragaw T (2018) Characterization of the Physicochemical and Biological Properties of Kombolcha Brewery Wastewater Treatment Plant Bio-solid in Relative to Agricultural Uses. Adv Recycling Waste Manag 3: 154. doi: $10.4172 / 2475-7675.1000154$

Page 2 of 7

generates $25 \mathrm{~m}^{3}$ of sludge per day and mostly dumped into the open land. This present disposal practice couldn't be feasible option when land disposal space is scarce and may cause environmental problems in future. Therefore, it is important to characterize the quality of the brewery sludge in order to develop feasible and sustainable treatment technique for better management and provide baseline data on the physicochemical, biological and heavy metal contents in the sludge to the industry, decision makers and local farmers who wants to start the practices of the sludge application for farming. Accordingly, the objective of this study was to characterize the physical, chemical and biological properties of brewery bio-solid/sludge (BS) generated from Kombolcha brewery wastewater treatment plant in relative to agricultural uses at least to substitute the 25,000 farmers urban horticultural (vegetables and fruits) activities including cereals in the town.

\section{Materials and Methods}

\section{Sludge sample sampling and preparation}

The source of sludge sample was Kombolcha brewery wastewater treatment plant, located in the Amhara regional state, northern part of Ethiopia. Sludge sampling was performed based on the EPA procedure [17]. The sludge was collected from the sedimentation tank daily for a period of three weeks. The collected sludge samples were mixed well and processed to obtain appropriate quality through air drying. The mixed sample was divided and conned to $1 \mathrm{Kg}$ to obtain a representative sludge sample for evaluating its physicochemical and biological characteristics including heavy metals in the laboratory. A 1 Kg dried sludge sample was ground with mortar and pestle and sieved by passing through $<2 \mathrm{~mm}$ stainless steel sieve and stored in the plastic bag for further laboratory analysis.

\section{Determination of sludge physicochemical and biological characteristics}

Three replicates of the sludge sample was taken for evaluation of the selected physicochemical and biological characteristics of the BS sample and each properties were determined as follows: the $\mathrm{pH}$ of the sludge/distilled water mixture (1:5) was determined using $\mathrm{pH}$ meter [18]; the electrical conductivity (EC) was measured from the sludge/ distilled water extract saturated paste [19]; the water holding capacity (WHC) was measured by Skene et al. [20]. Total solid (TS) and total fecal coliforms (TFC) were determined following standard procedure [21]; Total Kjeldhal Nitrogen (TKN) was determined using Kjeldhal method [22]; Organic carbon (OC) content was measured by loss of ignition (LOI) method [23]; organic matter (OM) content was estimated by multiplying total organic carbon content by the Van Bemmelen factor (1.724); major and minor mineral oxides of secondary plant nutrients and other nutrients of $\mathrm{K}_{2} \mathrm{O}, \mathrm{Na}_{2} \mathrm{O}, \mathrm{CaO}$, $\mathrm{MgO}, \mathrm{Fe}_{2} \mathrm{O}_{3}, \mathrm{MnO}, \mathrm{Al}_{2} \mathrm{O}_{3}, \mathrm{P}_{2} \mathrm{O}_{5}$ and $\mathrm{TiO}_{2}$ were measured through $\mathrm{LiBO}_{2}$ using AAS (Varian Spectr AA.20 Plus) at detection limit of $<0.01 \%$ and Colometric method and $\mathrm{SiO}_{2}$ was analyzed using $\mathrm{HF}$ attack and AAS (Varian Spectr AA.20 Plus) following [24-26] procedures.

\section{Heavy metals analysis in the brewery sludge}

The ground sludge sample $(1 \mathrm{~g})$ was placed in $25 \mathrm{ml}$ beakers and next, $10 \mathrm{ml} 69-70 \% \mathrm{HNO}_{3}$ and $10 \mathrm{ml} 35.4 \% \mathrm{HCl}$ (obtained from research lab-Fine Chem. Industries, Mumbai, India) were added along with $30 \% \mathrm{H}_{2} \mathrm{O}_{2}$ (Scharlau, European Union) following Method 3050 [27]. Selected soluble salts were used to prepare standard solutions for each element and a calibration curve was drawn from them in the instrument before unknown samples were used. Then, the total metal concentrations were determined using flame atomic absorption spectrophotometer (Shimadzu AA-7000, Japan) equipped with a deuterium background corrector and hollow cathode lamps with an air acetylene flame at wavelength $(\mathrm{nm})$ and detection limits (DL) of 228.8 and 0.02 for $\mathrm{Cd} ; 324.8$ and 0.035 for $\mathrm{Cu} ; 279.8$ and 0.03 for Mn; 240.7 and 0.075 for $\mathrm{Co} ; 283$ and 0.01 for $\mathrm{Pb} ; 357.9$ and 0.01 for $\mathrm{Cr} ; 213.9$ and 0.012 for $\mathrm{Zn} ; 232$ and 0.07 for Ni; 248 and 0.08 for Fe; 239 and 0.0035 for $\mathrm{Ca} ; 285.2$ and 0.035 for $\mathrm{Mg} ; 766.5$ and 0.02 for $\mathrm{K}$ and 589 and 0.007 for $\mathrm{Na}$ respectively.

\section{Descriptive statistical data analysis}

The sludge sample physicochemical, biological and heavy metal means, standard deviations and coefficient variation values were analyzed using R-software, version 3.2.2.

\section{Results and Discussion}

\section{Physicochemical and biological properties of BS}

The physicochemical and biological characterization of the BS was first investigated to evaluate its potential use for agricultural purpose. The main physical, chemical and biological properties of the sludge sample were present in Table 1 . The determination of the $\mathrm{pH}$ of brewery sludge was found slightly alkaline and it was found in the reported brewery sludge $\mathrm{pH}$ values ranging from 6.5 to 11.5 [28]. This slightly alkaline property of BS may be arising from certain $\mathrm{pH}$ adjustment measures taken to regulate fluctuations in the biological processes carried out in wastewater treatment plant. Sludge alkalinity or acidity is a key factor that affects the soil physical, chemical and biological characteristics and determines the availability of many nutrients for plant growth and maintenance $[29,30]$. The electrical conductivity (EC) of the sludge was $2.353 \mathrm{mS} / \mathrm{cm}$. This EC value lies in the reported EC of the refuse, waste soils values ranged from 1.38-3.12 $\mathrm{mS} / \mathrm{cm}$ [30]. The EC value meets the salinity limit value of $3 \mathrm{mS} / \mathrm{cm}$ to be used as a good fertilizer [31]. Beside this, it is almost equal to the standard, i.e., $\mathrm{EC}<2 \mathrm{mS} / \mathrm{cm}$ in soil, sludge and irrigation water which is generally a safe level for plants. However, most of the plants can tolerate EC values ranges from $3-4 \mathrm{mS} / \mathrm{cm}$ [32]. The EC of sludge is associated with salinity and it is used to indicate the soluble salt concentrations which exert severe stress on non-salt tolerant plants and inhibit the plant growth in the soil [33]. The EC value obtained in this study may be attributed due to the presence of soluble salts like sodium $\left(0.37 \mathrm{mg} / \mathrm{Kg}\right.$ as $\mathrm{Na}$ and $0.86 \%$ as $\left.\mathrm{Na}_{2} \mathrm{O}\right)$ and chloride content of the sludge, which comes from the use of sodium hydroxide $(\mathrm{NaOH})$ and ferric chloride $\left(\mathrm{FeCl}_{3}\right)$ in the wastewater treatment processes. The TS value was $92.93 \%$, which is quite high and implies that the sludge content can be used for different purposes like landfilling or land reclamation. The mean water holding capacity of the BS was $54 \%$. The higher WHC of this sludge may be due to the presence of the high OM content. According to Aboukila et al. investigation, soil amended with brewery spent grain showed significantly increased WHC as compared to other treatments [33]. Similarly, other research report also indicates that the addition of compost fertilizer and cow manure increased the water holding capacity of the soil [34], all these may be due to the positive correlations between OM content and available WHC of soil 
Citation: Alayu E, Leta S, Aragaw T (2018) Characterization of the Physicochemical and Biological Properties of Kombolcha Brewery Wastewater Treatment Plant Bio-solid in Relative to Agricultural Uses. Adv Recycling Waste Manag 3: 154. doi: $10.4172 / 2475-7675.1000154$

Page 3 of 7

[35]. The high WHC of Kombolcha brewery sludge implicates that it can have the capability to enhance the WHC of soil.

The total mean percentage of organic carbon and organic matter contents of brewery sludge were $49.1 \%$ and $84.6 \%$ respectively. The result of $\mathrm{OM}$ content found in this study was achieved Taiwan recommended regulations for specification of organic matter content (dry weight) $>50 \%$ for utilizing sludge as a material resource sustainable [36]. The OC content of BS obtained in this study was quite high and greater than the OC content of compost (consisted of animal waste and plant residues); i.e., 23.5\%, brewery sludge OC values of $43.3 \%$ [37] and $42.5 \%$ [38]. Generally, the high OC content found in the brewery sludge can make it a potential soil fertilizer, which can significantly increase the supplement of essential nutrients to crops, enriching the soil physical properties and boosting the organic matter content in the soil and overall contributing an increment in crop production. In literatures, an increased addition of $\mathrm{OM}$ increases the WHC, exchangeable ions, porosity, nutrient storage and turnover, decrease soil erosion, reduce soil acidity, and improve the microbial activity in the soil through utilizing $\mathrm{OM}$ as a source of food and in general, enhance full health and the optimum growth rate of plants [32,37-39].

$\mathrm{C} / \mathrm{N}$ ratio is one of the most important chemical characteristics of sludge for microorganisms; carbon is the building block of life and source of energy; while, nitrogen is necessary as proteins, genetic material and cell structure. The $\mathrm{C} / \mathrm{N}$ result obtained in this study was 12.78. This result is higher than the reported $\mathrm{C} / \mathrm{N}$ ratio of malting sludge (i.e., 7.47) [40], compost (i.e., 11.2) and brewery spent grain (i.e., 7.1) [33]. The result is also found in line with the allowable range of $\mathrm{C} / \mathrm{N}$ of the fertilizer value of sludge for agricultural use set by the environmental qualification authority $<35: 1[41,42]$. The carbon to nitrogen ratio ranged from 11.0 to 20.45 implicates that the soil would support plant species diversity and growth. Therefore, we can conclude that the $\mathrm{C} / \mathrm{N}$ ratio of brewery sludge obtained in this study can support the plant species diversity and growth.

The total Kjeldhal nitrogen (TKN) and phosphorus (as $\mathrm{P}_{2} \mathrm{O}_{5}$ ) contents in the sludge were $3.84 \%$ and $5.92 \%$ respectively. The TKN result obtained in this brewery sludge normally existed in the range of nitrogen concentration used by most plants, averages from $2-4 \%$. The obtained TKN result is higher than sewage sludge (1.97\%) [43], compost (consisted of animal waste and plant residues) (2.1\%) [33], and brewery sludge (1.33\%) [2], implies that it is quite sufficient enough for agricultural application. Nitrogen is a main macro-nutrient element and presence of it in high amounts, stimulates shoot growth and root growth. Because, nitrogen is needed to make chlorophyll besides the genetic proteins and cell walls needed by all cells [41]. Similarly, phosphorus is another essential element for plants which is absorbed by plant roots in the orthophosphate form and can boost plant growth [44]. The determined available phosphorus $(5.92 \%)$ is beyond the guideline values assigned by the environmental qualifications authority for the fertilizer value of sludge for agricultural use, $1.5-2 \%$ [42]. This $\mathrm{P}_{2} \mathrm{O}_{5}$ value is higher than the phosphorus content of the diary plant sludge $\left(2.4 \mathrm{Kgm}^{-3}\right)$ [12], and compost (consisted of animal waste and plant residues) (1.03\%) [34]. Therefore, the amount of available phosphorus found in this study is enough for plant uptake and sufficient for crop requirement. In general, the high $\mathrm{OM}$ and nutrient (nitrogen and phosphorus) contents found in this brewery sludge can serve as a valuable organic fertilizer.

The secondary macronutrients in terms of free and oxide forms in the sludge sample were also indicated in Table 1 along with their equations for calibration curves and correlation coefficients. The calcium content of the brewery sludge was $4.74 \%$ as $\mathrm{CaO}$ and 3.19 $\mathrm{mg} / \mathrm{Kg}$ as Ca. This value is lower when compared with Dolgen et al. [11] investigated the value of $\mathrm{Ca}$ in brewery sludge which is 5762 $\mathrm{mg} / \mathrm{Kg}$. But it contains significant quantities of $\mathrm{Ca}$ as compared to diary plant sludge $\mathrm{CaO}$ content $\left(2.0 \mathrm{Kgm}^{-3}\right)$ [12], and pulp and paper mill sludge which value ranged from $0.36-1.28 \%$ [32]. The concentration of magnesium was found $1.19 \mathrm{mg} / \mathrm{Kg}$ as $\mathrm{Mg}$ and $0.76 \%$ as $\mathrm{MgO}$ in the sludge. The achieved $\mathrm{Mg}$ content of the brewery sludge is observed lower in value than the brewery sludge $\mathrm{Mg}$ content of $5 \mathrm{~g} /$ $\mathrm{Kg}$ reported by Couce et al. respectively [45]. Measured potassium and sodium contents in the sludge were $(1.61 \mathrm{mg} / \mathrm{Kg}, 0.24 \%)$ and $(0.37 \mathrm{mg} /$ $\mathrm{Kg}, 0.86 \%)$ respectively in their free and oxide forms. In literature, the potassium content as $\mathrm{K}_{2} \mathrm{O}$ was varied between $0.1-1.95 \mathrm{~g} / \mathrm{Kg}$ [4]. The $\mathrm{K}$ content of this sludge sample is higher than $0.08 \mathrm{mg} / \mathrm{Kg}$ reported by Vriens et al. [46]. However, some reported research outputs proved that the potassium level in the sludge is usually low and can range from $0.02-2.64 \%$, but this is adequate enough for plant uptake and still sufficient for crop requirement Sommers [47]. The potassium content existed in this brewery sludge implies that it can be adequate enough for plant uptake. Similarly, the determined $\mathrm{Na}$ concentration was lower than the research report of Couce et al.[45] in the brewery sludge (i.e., $4.9 \mathrm{~g} / \mathrm{Kg}$ ), which has an advantages to avoid problems of salt accumulation in the plant root and saline nature of the soil. In general, Kombolcha brewery sludge was deficient in terms of secondary plant nutrients such as potassium, sodium, calcium and manganese. These deficient in values of secondary plant nutrients may be due to the quality of the bore and municipal water used in the malting process and probably no use of chemical additives for the production process or cleaning aids.

In brewery sludge, other varying amounts of essential micro elements were also found; the concentration of $\mathrm{Al}$ as $\mathrm{Al}_{2} \mathrm{O}_{3}$ and $\mathrm{Fe}$ as $\mathrm{Fe}_{2} \mathrm{O}_{3}$ and $\mathrm{Fe}$ was $2.94 \%, 5.84 \%$ and $10211.5 \mathrm{mg} / \mathrm{Kg}$ respectively. The level of $\mathrm{Al}$ content in the brewery sludge was within the range indicated by the United State Environmental Protection Agency, USEPA, 1983 [17]. The content of Fe in this study is lower than the iron content $(11,525 \mathrm{mg} / \mathrm{Kg})$ in residual sludge of malting barley Couce et al. [45]. The source of iron in this brewery sludge was due to the use of ferric chloride in the wastewater treatment processes for phosphorous removal through coagulation and precipitation. But, this iron is insufficient for agricultural uses. Because, measured iron content of the brewery sludge was $10211.5 \mathrm{mg} / \mathrm{Kg}$ while it should be $13000 \mathrm{mg} / \mathrm{Kg}$ in the literature [38]. The silicate $\left(\mathrm{SiO}_{2}\right)$ content in brewery sludge was $27.98 \%$, which is higher than the silicate content of dried sewage sludge ash (9.57\%) [48]. The source of this silica may be associated with the keiselguhr, is a diatomaceous earth that is rich in silicates from fossils of prehistoric algae (diatomite) [49]. The titanium content of BS was $0.18 \%$, which is lower than the titanium content $(0.949 \%)$ of dried sewage sludge ash reported by Tempest and Pando [50]. The source of titanium may be associated with paint pigment used to coat the sludge tank. Conversely, the $\mathrm{MnO}$ was below the detection limit of the instrument. In this experiment, the concentrations of total fecal coliforms (TFC) as fresh and dry weight in the brewery sludge sample were determined. The densities of the TFC in the dewatered fresh and dry weight were $5.46 \mathrm{CFU} / \mathrm{mL}$ and 3.06 $\mathrm{CFU} / \mathrm{mL}$ respectively (Table 1 ). The fresh weight TFC density of this sludge sample was higher than the E.coli content $(5 \mathrm{CFU} / \mathrm{g}$ ) of the brewery sludge reported by Ediget [51]. However, the air-dried sludge sample TFC content was lower than the reported value, indicates that air drying process reduces the TFC concentrations. In this regard, the 
Citation: Alayu E, Leta S, Aragaw T (2018) Characterization of the Physicochemical and Biological Properties of Kombolcha Brewery Wastewater Treatment Plant Bio-solid in Relative to Agricultural Uses. Adv Recycling Waste Manag 3: 154. doi: $10.4172 / 2475-7675.1000154$

Page 4 of 7

air-dried sludge sample TFC content found in this study was not meet the EPA standards of sludge (i.e., <10-3) and therefore, it should be stabilized for sustainable agricultural land reuse.

\begin{tabular}{|c|c|c|c|c|}
\hline \multirow[t]{2}{*}{ Sludge properties } & \multicolumn{3}{|l|}{ Values } & \multirow{2}{*}{$\begin{array}{l}\text { Equation for calibration curves and } \\
\text { Correlation coefficient }(r)\end{array}$} \\
\hline & Mean & Mean \pm SD & CV & \\
\hline $\mathrm{pH}$ & 7.85 & $7.85 \pm 0.005$ & 0.00066 & - \\
\hline $\mathrm{EC}(\mathrm{mS} / \mathrm{cm})$ & 2.35 & $2.35 \pm 2.52$ & 0.00107 & - \\
\hline WHC (\%) & 54.0 & $54.0 \pm 1.00$ & 0.01852 & - \\
\hline TS (\%) & 92.93 & $92.93 \pm 0.30$ & 0.00329 & - \\
\hline $\mathrm{OC}(\%)$ & 49.10 & $49.1 \pm 0.10$ & 0.00204 & - \\
\hline OM (\%) & 84.60 & $84.60 \pm 0.17$ & 0.00204 & - \\
\hline TKN (\%) & 3.84 & $3.84 \pm 0.038$ & 0.00985 & - \\
\hline $\mathrm{P}_{2} \mathrm{O}_{5}(\%)$ & 5.92 & $5.92 \pm 0.01$ & 0.00258 & $y=3.641 x+0.0 .0356, r=0.9993$ \\
\hline $\mathrm{K}_{2} \mathrm{O}(\%)$ & 0.24 & $0.24 \pm 0.01$ & 0.04167 & $y=0.0115 x-0.0125, r=0.9995$ \\
\hline $\mathrm{K}(\mathrm{mg} / \mathrm{Kg})$ & 1.61 & $1.61 \pm 0.38$ & 0.23785 & $y=0.3648 x+3 E-05, r=1.0000$ \\
\hline $\mathrm{Na}_{2} \mathrm{O}(\%)$ & 0.86 & $0.86 \pm 0.01$ & 0.01163 & $y=0.0146 x+0.0059, r=0.9990$ \\
\hline $\mathrm{Na}(\mathrm{mg} / \mathrm{Kg})$ & 0.37 & $0.37 \pm 0.02$ & 0.06667 & $y=0.0681 x+3 E-05, r=1.0000$ \\
\hline $\mathrm{CaO}(\%)$ & 4.74 & $4.74 \pm 0.23$ & 0.04852 & $y=0.0118 x-0.0025, r=0.9997$ \\
\hline $\mathrm{Ca}(\mathrm{mg} / \mathrm{Kg})$ & 3.19 & $3.19 \pm 0.34$ & 0.10598 & $y=0.697 x+0.115, r=0.9970$ \\
\hline $\mathrm{MgO}(\%)$ & 0.76 & $0.76 \pm 0.01$ & 0.09210 & $y=0.0236 x+0.0162, r=0.9998$ \\
\hline $\mathrm{Mg}(\mathrm{mg} / \mathrm{Kg})$ & 1.19 & $1.19 \pm 0.26$ & 0.21625 & $y=0.1883 x+2 E-16, r=0.998$ \\
\hline $\mathrm{Fe}_{2} \mathrm{O}_{3}(\%)$ & 5.84 & $5.84 \pm 0.01$ & 0.04794 & $y=0.0208 x+0.0594, r=0.9856$ \\
\hline $\mathrm{MnO}(\%)$ & $<0.01$ & ND & - & $y=0.076 x+0.0015, r=0.9991$ \\
\hline $\mathrm{Al}_{2} \mathrm{O}_{3}(\%)$ & 2.94 & $2.94 \pm 0.07$ & 0.02381 & $y=0.001 x+0.0003, r=0.9991$ \\
\hline $\mathrm{SiO}_{2}(\%)$ & 27.98 & $27.98 \pm 1.09$ & 0.03896 & $y=0.016 x-0.0106, r=0.9999$ \\
\hline $\mathrm{TiO}_{2}(\%)$ & 0.18 & $0.18 \pm 0.01$ & 0.055556 & $y=0.1107 x+0.0755, r=0.8952$ \\
\hline $\mathrm{C} / \mathrm{N}$ ratio & 12.78 & $12.78 \pm 0.11$ & 0.00837 & - \\
\hline $\mathrm{FC}(\mathrm{CFU} / \mathrm{ml})$ as $\mathrm{FW}$ & 5.46 & $5.46 \pm 0.02$ & 0.81649 & - \\
\hline $\mathrm{FC}(\mathrm{CFU} / \mathrm{ml})$ as $\mathrm{DW}$ & 3.06 & $3.06 \pm 0.01$ & 0.81649 & - \\
\hline
\end{tabular}

Table 1: Physicochemical and biological properties of brewery sludge.

\section{Heavy metals concentration of BS}

The heavy metals concentration of the brewery sludge is presented in Table 2 together with the equation for calibration curves, correlation coefficients ( $r$ ) and the recommended EPA limits for sludge and Canadian allowable Limits for compost in agricultural use. The mean concentration of lead $(\mathrm{Pb})$, zinc $(\mathrm{Zn})$, and copper $(\mathrm{Cu})$ were $0.05,0.07$ and $0.77 \mathrm{mg} / \mathrm{Kg}$ respectively. On the contrary, the concentrations of cadmium (Cd), chromium (Cr), cobalt (Co), manganese $(\mathrm{Mn})$, and nickel $(\mathrm{Ni})$ were below the detection limits of the instrument. The

previously reported research result of the $\mathrm{Pb}$ content in the same factory liquid waste was $214 \mu \mathrm{g} / \mathrm{L}$ [51]. In the same regard, $0.05 \mathrm{mg} / \mathrm{Kg}$ lead was also found in the sludge sample of this factory. The $\mathrm{Pb}$ content found in this study is very low when compared to the $\mathrm{Pb}$ contents of $33.88 \mu \mathrm{g} / \mathrm{g}$ in the brewery sludge [52], and the maximum allowable limit of $\mathrm{Pb}$ content recommended for agriculture by EPA [53] and Canadian class A limits (Table 2). The probable source of $\mathrm{Pb}$ in the sludge may be due to emission from the exhaust pipe of the generating plant used to power the machines during production. The copper 
Citation: Alayu E, Leta S, Aragaw T (2018) Characterization of the Physicochemical and Biological Properties of Kombolcha Brewery Wastewater Treatment Plant Bio-solid in Relative to Agricultural Uses. Adv Recycling Waste Manag 3: 154. doi: $10.4172 / 2475-7675.1000154$

Page 5 of 7

content of the sludge was $0.77 \mathrm{mg} / \mathrm{Kg}$ which is below the EPA $[53,54]$ standard limits of $4300 \mathrm{mg} / \mathrm{Kg}$ and Canadian class A limit of 400 $\mathrm{mg} / \mathrm{Kg}$. Cu content is appeared low compared to other published values for the brewing effluent sludge (i.e., $110 \mathrm{mg} / \mathrm{Kg}$ ) [46], and sewage sludge ranges from $85-2900 \mathrm{mg} / \mathrm{Kg}$ [17]. The possible way of contamination of the BS with $\mathrm{Cu}$ may be due to the chemical additives in the brewery making process and presence of cyan ink. The $\mathrm{Zn}$ content of the sludge is again below EPA [53] class limit of $7500 \mathrm{mg} / \mathrm{Kg}$ and Canadian allowable class A limit of $700 \mathrm{mg} / \mathrm{Kg}$. The $\mathrm{Zn}$ content found in this result is also lower than the previous reported $\mathrm{Zn}$ content in the brewery and sewage sludges by Alemu et al. [2] and Ize-Imayu et al. [55] which are $28.5 \mathrm{mg} / \mathrm{Kg}$ and $3.20 \mathrm{mg} / \mathrm{L}$ respectively. Similar to others, the probable source of $\mathrm{Zn}$ contamination in the BS may be attributed from water pipes, wastewater planting works and storage tanks.

In general, the content of $\mathrm{Cu}, \mathrm{Zn}$ and $\mathrm{Pb}$ found in this brewery sludge sample were much lower than tannery sludge heavy metals content of $\mathrm{Cu}(80 \mathrm{mg} / \mathrm{Kg}), \mathrm{Zn}(200 \mathrm{mg} / \mathrm{Kg})$, and $\mathrm{Pb}(10 \mathrm{mg} / \mathrm{Kg})$ [55]. Heavy metals like $\mathrm{Fe}, \mathrm{Zn}$ and $\mathrm{Cu}$ are required at appropriate concentrations for structural and catalytic components of proteins and enzymes as cofactor and essential for normal growth of plants [56]. However, beyond the optimal concentrations, these micronutrients and other heavy metals in plants operate a stress factor $[57,58]$. Therefore, the heavy metals concentration in the industrial sludge is one of the major issues as it needs to be verified that either they are above the critical limits or not. Generally, the heavy metals concentration found in this brewery sludge are much lower than the recommended concentrations of EPA [53] standards for all sludge and Canadian class A limit for compost. This positive outcome of the research result can be a good source of information to the local community who wants to start this sludge for agricultural application in environmentally friendly approach with no risk of heavy metal toxicity.

\begin{tabular}{|c|c|c|c|c|c|c|}
\hline \multirow[t]{2}{*}{ Heavy Metals } & \multicolumn{3}{|c|}{ Concentration of metals $(\mathrm{mg} / \mathrm{Kg})$} & \multirow{2}{*}{$\begin{array}{l}\text { Equation for calibration curves and } \\
\text { Correlation coefficient }(r)\end{array}$} & \multicolumn{2}{|c|}{ Standards } \\
\hline & Mean & Mean \pm SD & CV & & 1 & 2 \\
\hline $\mathrm{Zn}$ & 0.07 & $0.07 \pm 0.02$ & 0.23766 & $y=0.39 x-0.0102, r=0.989$ & 700 & 7,500 \\
\hline $\mathrm{Pb}$ & 0.05 & $0.05 \pm 0.01$ & 0.32695 & $y=0.058 x-0.0021, r=0.991$ & 150 & 840 \\
\hline $\mathrm{Cu}$ & 0.77 & $0.77 \pm 0.05$ & 0.06330 & $y=0.819 x-0.0234, r=0.991$ & 400 & 4,300 \\
\hline $\mathrm{Fe}$ & 10211.5 & $10211.5 \pm 10$ & 0.00015 & $y=0.062 x+0.0024, r=0.998$ & - & - \\
\hline $\mathrm{Cd}$ & ND & ND & - & $y=0.0426 x+0.0008, r=0.992$ & - & - \\
\hline $\mathrm{Cr}$ & ND & ND & - & $y=0.5197 x-0.0144, r=0.990$ & - & - \\
\hline Co & ND & ND & - & $y=0.066 x-0.0022, r=0.988$ & - & - \\
\hline $\mathrm{Ni}$ & ND & ND & - & $y=1.0102 x-0.0362, r=0.989$ & - & - \\
\hline $\mathrm{Mn}$ & ND & ND & - & $y=0.0581 x-0.0008, r=0.992$ & - & - \\
\hline
\end{tabular}

Table 2: Concentrations of heavy metals in brewery sludge and recommended standards.

\section{Conclusion}

Characterization of the BS revealed that the presence of important primary nutrients like nitrogen, phosphorus and secondary nutrients such as potassium, calcium, magnesium, sodium and others like iron, copper and aluminum with high organic matter content, high water holding capacity in combination with very low concentration of heavy metals that meets the allowed EPA ceiling standards for recycling biosolids for agricultural purposes can be a potential source of cheap fertilizer without risk of heavy metal toxicity. However, the pathogen content was high which needs further treatment to achieve the limit before introduced into agricultural application. Therefore, a cost effective, user friendly technique should develop to convert brewery sludge into a bio-fertilizer that can substitute the need of inorganic fertilizers at least for the 25,000 farmers urban horticultural (vegetables and fruits) activities including cereals in the study area.

\section{Acknowledgements}

The authors honestly acknowledge the Kombolcha brewery factory Management teams for their patience, friendly approach and collaboration for the accomplishment of this work. The authors also likely to express their gratitude to the Geological Survey of Ethiopia: Geochemical laboratory and Addis Ababa University Centre for environmental science; providing us to get laboratory access for sludge sample physicochemical and heavy metal analysis.

\section{References}

1. Alayu E, Yirgu Z (2017) Advanced Technologies for the Treatment of Wastewaters from Agro-processing Industries and Cogeneration of Byproducts: A Case of Slaughterhouse, Diary and Beverage Industries. Int J Environ Technol, pp: 1-16.

2. Alemu N, Ahmed A, Mohammed M (2016) Impact of Brewery Waste Sludge on Productivity and Soil Fertility in Harari Regional State, Eastern Ethiopia. Adv Crop Sci Tech 4: 242. 
Citation: Alayu E, Leta S, Aragaw T (2018) Characterization of the Physicochemical and Biological Properties of Kombolcha Brewery Wastewater Treatment Plant Bio-solid in Relative to Agricultural Uses. Adv Recycling Waste Manag 3: 154. doi: $10.4172 / 2475-7675.1000154$

Page 6 of 7

3. Kanagachandran K, Jayaratne R (2006)Utilization Potential of Brewery Wastewater Sludge as Organic Fertilizer. J Inst Brew 112: 92-95.

4. Spinosa L, Vesilind PA (2001) Sludge into Bio-solids, London: IWA Publishing.

5. Hseu YZ (2004) Evaluating Heavy Metal Contents in nine Composts using four Digestion Methods. Bio Technol 95: 53-59.

6. Asia IO, Ekpo KE, Chukwuedo ME (2008) Economic Importance and Application Options of some Industrial Sludge Conditioned by Different Treatment Methods. African J Biotechnol 7: 24-34.

7. Thomas KR, Rahman PKSM (2006) Brewery Wastes. Strategies for Sustainability-A Review. Aspects of Appl Bio 80: 147-153.

8. Bjuhr J (2007) Trace Metals in Soils Irrigated Wastewater in a Periurban Area Downstream Hanoi City, Vietnam.

9. Lynda KD, Chaney K, Murray C, Sckrabani R, Gedara S (2015) Studies on Effect of Brewery Wastewater Sludge (BWS) on Morphology and Yield of Chilly (Capsicum Annum L.). Plant, Intern J Pharmaceu Sci Res 6: 405-409.

10. Babel S, Sae-Tang J, Pecharaply A (2009) Anaerobic Co-digestion of Sewage and Brewery Sludge for Biogas Production and Land Application, Intern J Sci Technol 6: 131-140.

11. Dolgen D, Alpaslan NM, Delen N (2004) Use of an Agro-Industry Treatment Plant Sludge on Iceberg Lettuce Growth. Ecol Eng 23: 117-119.

12. Lopez-Mosquera EM, Carral EMC (2000) Use of Diary-Industry Sludge as Fertilizer for Grasslands in Northwest Spain: Heavy Metal Levels in the Soil and Plants. Res Conserv Recyc 30: 96.

13. Arthurson V (2008) Proper Sanitization of Sewage: Sludge: A Critical Issue for Sustainable Society. Appl Environ Microbio 74: 5267-5275.

14. Mondal S, Singh RD, Patra AK, Dwivedi BS (2015) Changes in Soil Quality in Response to Short-term Application of Municipal Sewage Sludge in a typic Haplustept under Cowpea-Wheat Cropping System. Environ Nanotechnol Monitor Manag 4: 37-41.

15. Erdem N, Suzudogru OS (2002) Effect of Brewery Sludge Amendements on some Chemical Properties of acid Soil in Pot Experiments. Biores Technol 84: 271-273.

16. Jolly G, Ashwani K (2012) Effect of Different Soil Types on Growth and Productivity of Euphorbia lathyrisl, a Hydrocarbon Yielding Plant. Intern J Life Sci Pharma Res 2: 164-173.

17. EPA (1983) United States Environmental Protection Agency ProcessDesign manual for land application of municipal sludge. EPA-625/1-83-016. Cincinnati (Ohio, USA): USEPA, pp: 446.

18. McLean EO (1982) Soil pH and Lime Requirement-Methods of Soil Analysis, (2nd ed.)) Agron. Monogr.9. ASA-CSSA-SSSA. Madison, Wisconsin, pp: 199-224.

19. Rhoades JD (1982) Soluble Salts-Methods of Soil Analysis (2nd ed.,) Agron. Monogr.9. ASA-CSSA-SSSA. Madison, WI, pp: 167-180.

20. Skene TM, Oades JM, Kilmore G (1995) Water Treatment Sludge: A Potential Plant Growth Medium. Soil Use Manage 11: 29-33.

21. APHA (1999) Standard Methods for Examination of Water and Wastewater, (20th ed.)) American Public Health Association, Washington, DC.

22. Bremner JM, Mulvaney CS (1982) Nitrogen-Total. Page A, et al. (Eds.) Methods of Soil Analysis, (2nd ed.,) American Society of Agronomy, Madison, WI, pp: 595-624.

23. Nelson DW, Sommers LE (1996) Total Carbon, Organic Carbon, and Organic Matter, in Methods of Soil Analysis. Chem Met, pp: 961-1009.

24. Kreshkove PA, Yaroslavtsev AA (1977) Course of Analytical Chemistry in two Volumes, Mir Publishers.

25. Easton JA (1972) Methods in Geochemistry and Geophysics; Chemical Analysis of Silicate Rocks.

26. Stanton ER (1966) Rapid Methods of Trace Analysis for Geochemical Applications.

27. Edgell K (1989) USEPA Method Study 37 SW-846 Method 3050 Acid Digestion of Sediments, Sludges, and Soils: US Environmental Protection Agency, Environmental Monitoring Systems Laboratory.
28. Luque O, Bracho O, Maier TW (1990) Utilization of Brewery Wastewater Sludge for Soil Improvement. Tech Q Master Brew Assoc Am 27: 5-9.

29. Arias ME, Gonzalez-Perez JA, Gonzalez-Villa FJ, Ball AS (2005) Soil Health: A new Challenge for Microbiologists and Chemists. Int Microbiol 8: 13-21.

30. Obasi AN, Akubugwo IE, Ugbogu CD, Otuchristian G (2012)Assessment of Physicochemical Properties and Heavy Metals Bioavailability in Dumpsites along Enugu-port Harcourt Expressways, Southeast, Nigeria. Asian J Appl Sci 5: 345.

31. Sumare M, Tack FMG, Verloo MG (2003) Characterization of Malian and Belgian Solid Waste Composts with Respect to Fertility and Suitability for Land Application. Waste Mange 23: 517-522.

32. Abdullah R, Ishak FC, Kadir RW, Bakar AR (2015) Characterization and Feasibility Assessment of Recycled Paper Mill Sludges for Land Application in Relation to the Environment. Int J Environ Res Publ Heal 12: 9319.

33. Mtshali SJ, Tiruneh TA, Fadiran OA (2014) Characterization of Sewage Sludge Generated from Wastewater Treatment Plants in Swaziland in Relation to Agricultural Uses. Resour Environ 4: 190-196.

34. Aboukila FE, Nassar NI, Rashad M, Hafez M, Norton BJ (2016) Reclamation of Calcareous Soil and Improvement of Squash Growth using Brewers' Spent Grain and Compost. J Saudi Soc Agricul Sci, pp: 15-20.

35. Vengadaramana A, Jashothan PTJ (2012) Effect of Organic Fertilizers on the Water Holding Capacity of Soil in Different Terrains of Jaffna Peninsula in Sri Lanka. J Nat Prod Plant Resour 2: 500-503.

36. Hudson BD (1994) Soil Organic Matter and Available Water Holding Capacity. J Soil Water Conserv 49: 189-194.

37. Tsai TW (2012) An Analysis of Waste Management Policies on Utilizing Bio-sludge as Material Resources in Taiwan. Sustain 4: 1885.

38. Sengun T (2007) Use of Agro - Industry Treatment Plant Sludge for Agricultural Purposes. Dokuzeylul University.

39. Erdem N, Suzudogru OS (2002) Effect of Brewery Sludge Amendements on some Chemical Properties of acid Soil in Pot Experiments. Bio Techn 84: 271-273.

40. Sampson EI (2016) Fertilizer Value of Bio-solids Produced from the Treatment of Waste Water Sludge, TLEP. Int J Chem Eng Res 2: 15-16.

41. Olsen T, Griffiths BS, Henriksen K, Moldrup P, Wheatley R (1997) Modeling Diffusion and Reaction in Soils: Nitrogen Transformations in Organic Manure Amended Soil. Soil Sci 162: 157-168.

42. Meghari ARA, Omar KR (2017) Physicochemical Characterization of Sewage Sludge of Gaza Wastewater Treatment Plant for Agricultural Utilization. J Nat Studies 25: 72-78.

43. Cheraghi M, Sobhanardakani S, Lorestani B (2015) Effects of Sewage Sludge and Chemical Fertilizers on $\mathrm{Pb}$ and $\mathrm{Cd}$ Accumulation in Fenugreek (Trigonella gracum). Iranian J Toxicol 9: 1348-1350.

44. Tisdale SL, Nelson WL, Beaton JD, Havlin J (1993) Soil Fertility and Fertilizer. Macmillan Publishing Co.

45. Campana DH, Echevaria MEU, Airasca AO, Andrade Couce ML (2014) Physicochemical and Phytotoxic Characterization of Residual Sludge from the Malting of Barley. J Pollut Eff Cont 2: 115.

46. Vriens L, Van Soest H, Verachtert H (1990) Biological Treatment of Malting and Brewing Effluents. Crit Rev Biotechnol 10: 1-46.

47. Sommers LE (2000) Chemical Composition of Sewage Sludge and Analysis of their Potential use as Fertilizers. J Environ Qual 6: 220- 225.

48. Tempest QB, Pando AM (2013) Characterization and Demonstration of Reuse Applications of Sewage Sludge Ash. Int J Geo 4: 552.

49. Mathias TR, demello PP, Camporese Servulo FE (2014) Solid Wastes in Brewing Process: A review. J of Brewing Distill 5: 7 -8.

50. Tempest QB, Pando AM (2013) Characterization and Demonstration of Reuse Applications of Sewage Sludge Ash. Int J Geomate 4: 552.

51. Ediget W (2016) The Fertilizing Potential of Breweries Waste Water Sludge Compared to Urea on the Growth and Yields of Tomato Plant, Published MSc. Thesis, Addis Ababa University, Ethiopia, pp: 7-22. 
Citation: Alayu E, Leta S, Aragaw T (2018) Characterization of the Physicochemical and Biological Properties of Kombolcha Brewery Wastewater Treatment Plant Bio-solid in Relative to Agricultural Uses. Adv Recycling Waste Manag 3: 154. doi: $10.4172 / 2475-7675.1000154$

Page 7 of 7

52. Alemu M, Sahu O (2015) Assessment of Heavy Metals in Borkena River in South Wollo, Ethiopia. J Envi Treat Techn 3: 118.

53. Khanal RB, Shah CS, Sah KS, Shriwastav PC, Acharya SB (2014) Heavy Metals Accumulation in Cauliflower (Brassica Oleracea L. var. Botrytis) Grown in Brewery Sludge Amended Sandy Loam Soil. Int J Agri Sci Tech 2: 87.

54. EPA (1994) A plain English Guide to the EPA: Part 503 Biosolids Rule, U.S. Environmental Protection Agency, Office of Wastewater Management, Washington D.C., USA, p: 178.

55. Ize-Iyamu KO, Eguavoen O, Osuide $\mathrm{M}$, Egbon $\mathrm{EE}$, Ize-Iyamu $\mathrm{CO}$, et al. (2000) Chemical Composition of Sewage Sludge and Analysis of their Potential use as Fertilizers. J Environ Qual 6: 220-225.
56. Ahmed M, Indris A, Omar SR (2007) Physicochemical Characterization of Compost of the Industrial Tannery Sludge. J Eng Sci Tech 2: 84.

57. Onyango JP, Kwarteng M (2011) Safe Vegetable Production with Wastewater in Developing Countries: Demystifying the Negative Notions, African J Horti Sci 5: 70-83.

58. Karanja PM (2011) Suitability Of Waste Water Sludge For Agricultural Use: A Case Study of Ruai Sewage Treatment Plant, Nairobi, Kenya, Published MSc., Thesis, p: 2. 